\title{
Analysis on the Impact of Bank Interest Rate Changes on Real Estate Financial Markets
}

\author{
Lu Siting
}

Renmin University of China, Beijing, 100872, China

Keywords: Interest rate, Real estate, Finance, influence

\begin{abstract}
After 40 years of development in China's real estate market, under the influence of changes in the domestic and international economic situation, it has formed a development characteristics in line with China's national conditions. At present, the domestic real estate financial market is affected by the state's macro-control policies, land policies, interest rate mechanisms, etc., and the domestic real estate financial market presents a characteristic development situation under the influence of complex factors.
\end{abstract}

\section{Introduction}

At present, China's economy is in a critical period of structural adjustment and transformation and upgrading. Domestic economic growth slowdown and industrial structure transformation and upgrading are intertwined, especially in some regions where government relies heavily on land finance and social financing leverage. The rate of non-performing loans of financial institutions, especially commercial banks, continues to rise. In this context, the supply and demand of the real estate market is divided, the housing prices in the first and second tier cities are rising too fast, and the third- and fourth-tier cities are intertwined with various problems. The international exchange rate situation is complex and changeable, and the innovation and supervision of the domestic real estate financial system is accelerated. Contradictions such as the need to improve the system, and so on, have led to an increase in the real estate market and the unstable factors of the real estate financial system. Therefore, in order to maintain a high degree of attention to the financial risks brought about by the changes in the domestic real estate industry during the economic transformation and upgrading period, and to explore effective strategies for dealing with risks, this is the basic standpoint of this study.

\section{Impact of policy changes on real estate financial markets}

At this stage, domestic and foreign scholars have carried out a lot of research on the risks of the real estate market. The vast majority of research targets are market risks in real estate, not financial risks in real estate.

\begin{tabular}{c|c|c|c}
\hline years & $\begin{array}{c}\text { Real estate investment } \\
(\mathbf{1 0 0} \text { million yuan) })\end{array}$ & $\begin{array}{c}\text { Fixed assets investment } \\
\mathbf{( 1 0 0} \text { million yuan) }\end{array}$ & Real estate investment \\
\hline 2016 & 102581 & 596501 & $17.2 \%$ \\
\hline 2015 & 95979 & 551590 & $17.4 \%$ \\
\hline 2014 & 95035.61 & 502005 & $18.9 \%$ \\
\hline 2013 & 86013.38 & 436528 & $19.7 \%$ \\
\hline 2012 & 71803.79 & 364835 & $19.7 \%$ \\
\hline 2011 & 61796.89 & 301933 & $20.5 \%$ \\
\hline 2010 & 48259.4 & 278140 & $17.4 \%$ \\
\hline 2009 & 36241.81 & 224846 & $16.1 \%$ \\
\hline
\end{tabular}

Figure 1 The proportion of real estate investment and fixed assets in China in recent years

As far as housing companies are concerned, if leverage is moderately beneficial to the 
development of housing enterprises, industrial expansion will benefit profits. However, once the leverage ratio exceeds a certain limit, resulting in excessive debt growth, the instantaneous increase in debt repayment pressure will adversely affect the development of enterprises.

The indicator of asset-liability ratio reflects the proportion of debt financing to total assets. It can be calculated by the ratio of total assets to total assets, which is a fuzzy comprehensive evaluation of the company's debt level. At the same time, the indicator reflects the ability of the company to use creditor funds for business activities in a certain process, reflecting the security level of creditors' loans.

Under the full market conditions, the mechanism of interest rate policy is relatively simple. For example, in the real estate economic boom, in order to curb the scale of real estate investment and the sharp increase in house prices, the central bank usually raises the benchmark interest rate. Its mechanism of action is as follows:

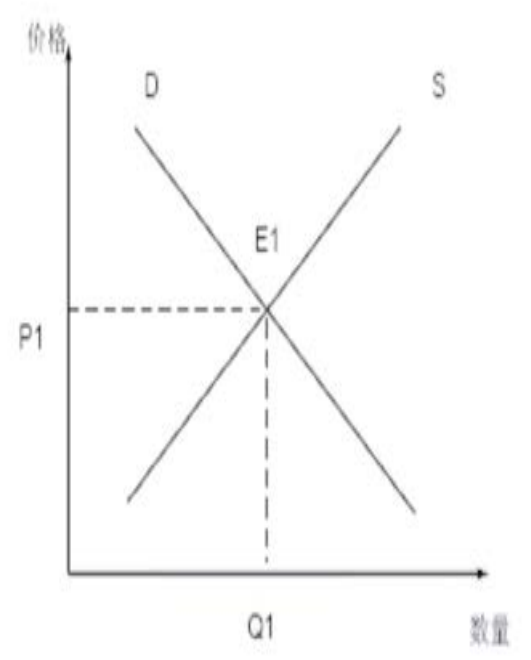

Figure 2 supply and demand

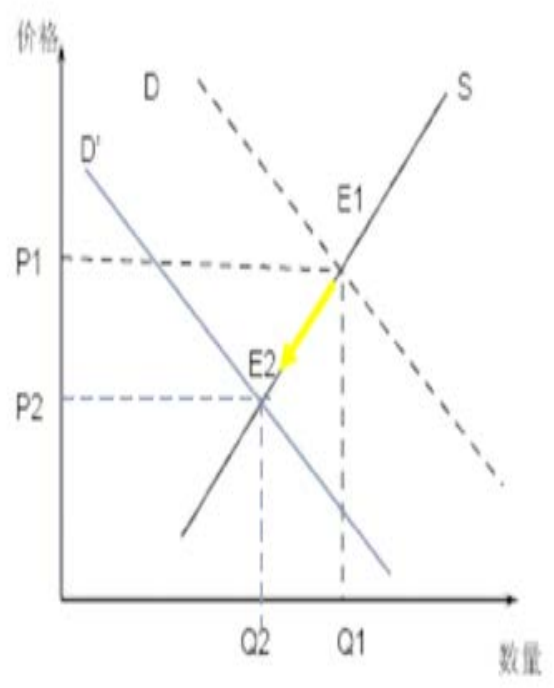

Figure 3 Short-term impact analysis 


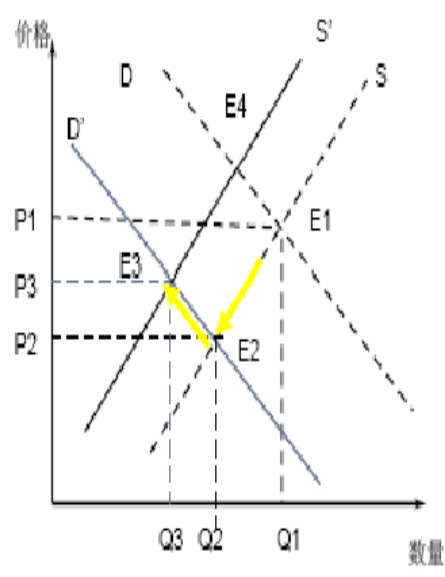

Figure 4 Long-term impact analysis

\section{The impact of interest rates on real estate financial markets}

\subsection{Interest rate and real estate price are negatively related}

Interest rates involve two aspects of the real estate market: one is the real estate development loan interest rate, and the other is the personal housing mortgage loan interest rate. For real estate developers, if the bank's interest rate increases, it will increase the cost of financing, so that real estate developers will reduce their willingness to invest, the total amount of real estate supply will begin to decrease, the market will be in short supply, and housing prices will rise. For buyers, if the interest rate rises, the cost of buying a house will increase, the monthly repayment pressure will be increased, and the willingness to purchase real estate will be

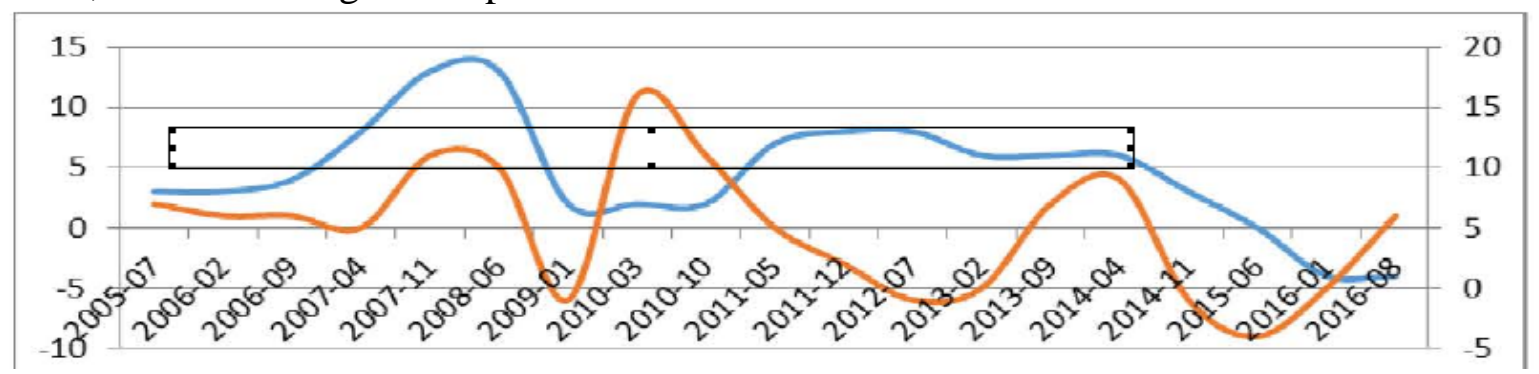

Figure 5. China's housing price fluctuations and interest rates

\subsection{The positive supply of money and real estate prices}

Money supply refers to the total amount of capital available for use, which can directly affect the amount of credit funds of banks, which not only affects housing investment but also affects daily consumption. Ultimately, real estate prices are also affected. In recent years, China has continuously adopted an active monetary policy of quantitative easing, issuing a large amount of money to increase the intensity of economic stimulation. This led to a large part of the market stocks entering the real estate market, which in the later period became the driving force for rising house prices.

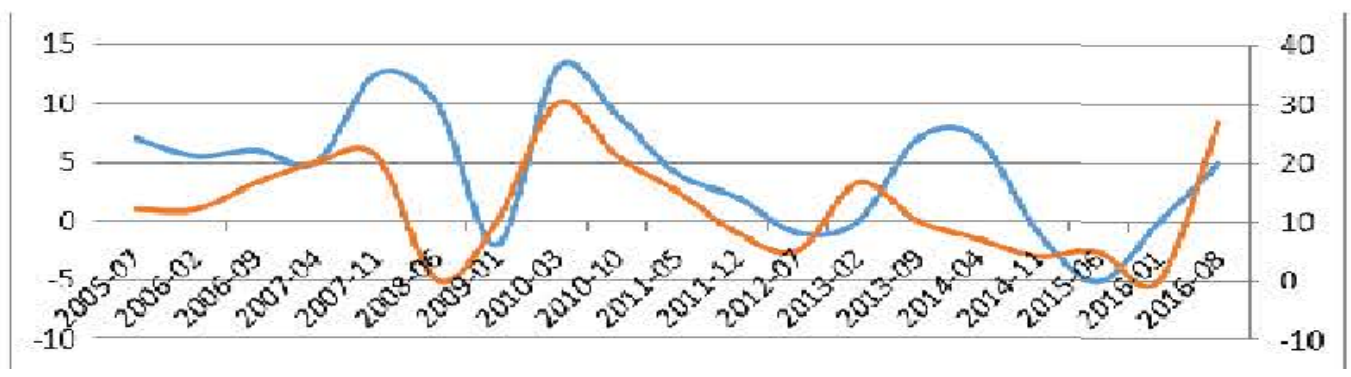

Figure 6 China's housing price fluctuations and currency 


\subsection{The increase in loan interest rate will directly curb consumer demand for home purchases}

The central bank raised the benchmark interest rate for loans, which will increase the loan expenses of home buyers to a certain extent. For some consumers who use loan financing to purchase real estate, the increase in interest rates will lead to an increase in financing costs. At the same price level, demand will fall. At the same time, the increase in loan interest rates may cause some homebuyers to repay in advance. After the loan interest rate is raised, some buyers will pay off all or part of the loan in advance of the implementation of the new interest rate to avoid interest expenses. Raising interest rates on loans may curb demand from homebuyers, reduce loan quotas, or delay home purchases. The loan interest rate adjustment has little effect on the rigid demand group like housing consumption. For the middle-income and middle-income groups, this part of the buyers may be forced to reduce the loan quota. For the low-income group, the cost of housing purchase may be temporarily considered. qiut the market.

\section{Policy recommendations}

The increase in loan interest rate has increased the financing cost for real estate developers, but there is no necessary positive correlation between the increase in loan interest rate and housing prices. The trend of housing prices is ultimately controlled by supply and demand. China's real estate market is not a sound market. The formation mechanism of real estate prices rising too fast is very complicated. There are many deep-seated reasons for the imbalance between supply and demand in China's real estate market. It is often at these deep levels that the central bank's financial means are used to regulate the market. The effect is weakened and the target is distorted by the cause.

To curb the rapid growth of housing prices, and fundamentally protect the sustainable and healthy development of the real estate industry, it is also necessary to start from the supply and demand relationship in the real estate market, ensure the basic balance of supply and demand in the real estate market, and promote the sustainable and healthy development of the real estate market. The first is to establish a scientific concept of development and regulate local government behavior. The second is to strictly control the total amount of land supply and put the land into the market. The third is to strictly control the scale of credit and curb the expansion of investment demand. . The fourth is to provide operational parameters of the real estate market and guide the decision-making of supply and demand. The fifth is to establish and improve the legal system and form a binding mechanism for real estate enterprises.

\section{References}

[1] Lei F. An Analysis of the Impact of Bank Credit and Interest Rate Adjustment on Real Estate Price[J]. West China Finance, 2012.

[2] Saba K, Kudła J. The impact of NBP's interest rate changes on the changes and volatility of WIG20[J]. Central European Economic Journal, 2014, 37.

[3] Lei, Fei. "An Analysis of the Impact of Bank Credit and Interest Rate Adjustment on Real Estate Price." West China Finance (2012).

[4] Saba, K., \& Kudła, J. (2014). The impact of nbp's interest rate changes on the changes and volatility of wig20. Central European Economic Journal, 37.

[5] Akimov A, Lee C L, Stevenson S. The Sensitivity of European Publically Listed Real Estate to Interest Rates[J]. Eres, 2015.

[6] Akimov, A., Lee, C. L., \& Stevenson, S. (2015). The sensitivity of european publically listed real estate to interest rates. Eres. 